
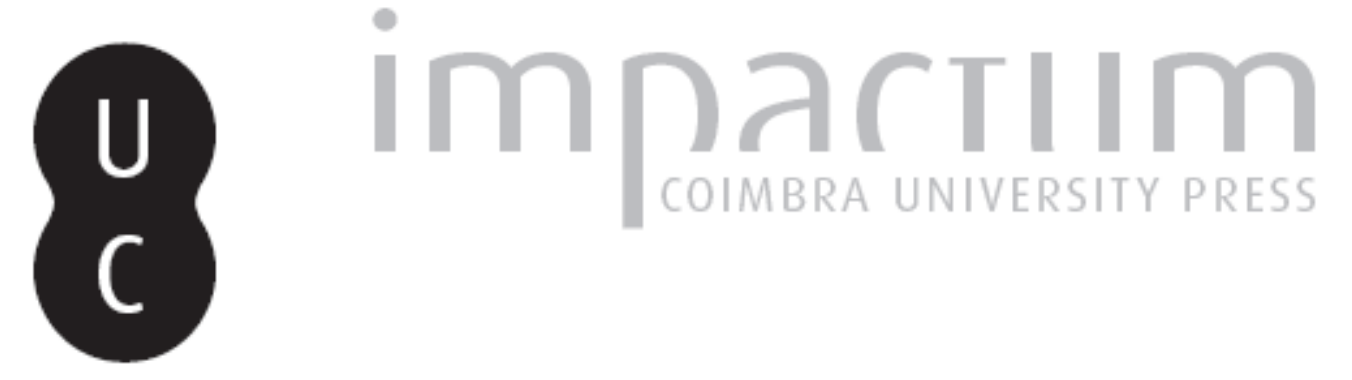

\title{
Three times modern: three projects, three different spheres, and scales; three different stories
}
Autor(es):
Peixoto, Marta

Publicado por: Editorial do Departamento de Arquitetura

URL persistente:

URI:http://hdl.handle.net/10316.2/45188

DOI:

DOI:https://doi.org/10.14195/1647-8681_9_10

Accessed : $\quad$ 26-Apr-2023 10:32:53

A navegação consulta e descarregamento dos títulos inseridos nas Bibliotecas Digitais UC Digitalis, UC Pombalina e UC Impactum, pressupõem a aceitação plena e sem reservas dos Termos e Condições de Uso destas Bibliotecas Digitais, disponíveis em https://digitalis.uc.pt/pt-pt/termos.

Conforme exposto nos referidos Termos e Condições de Uso, o descarregamento de títulos de acesso restrito requer uma licença válida de autorização devendo o utilizador aceder ao(s) documento(s) a partir de um endereço de IP da instituição detentora da supramencionada licença.

Ao utilizador é apenas permitido o descarregamento para uso pessoal, pelo que o emprego do(s) título(s) descarregado(s) para outro fim, designadamente comercial, carece de autorização do respetivo autor ou editor da obra.

Na medida em que todas as obras da UC Digitalis se encontram protegidas pelo Código do Direito de Autor e Direitos Conexos e demais legislação aplicável, toda a cópia, parcial ou total, deste documento, nos casos em que é legalmente admitida, deverá conter ou fazer-se acompanhar por este aviso.

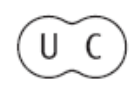



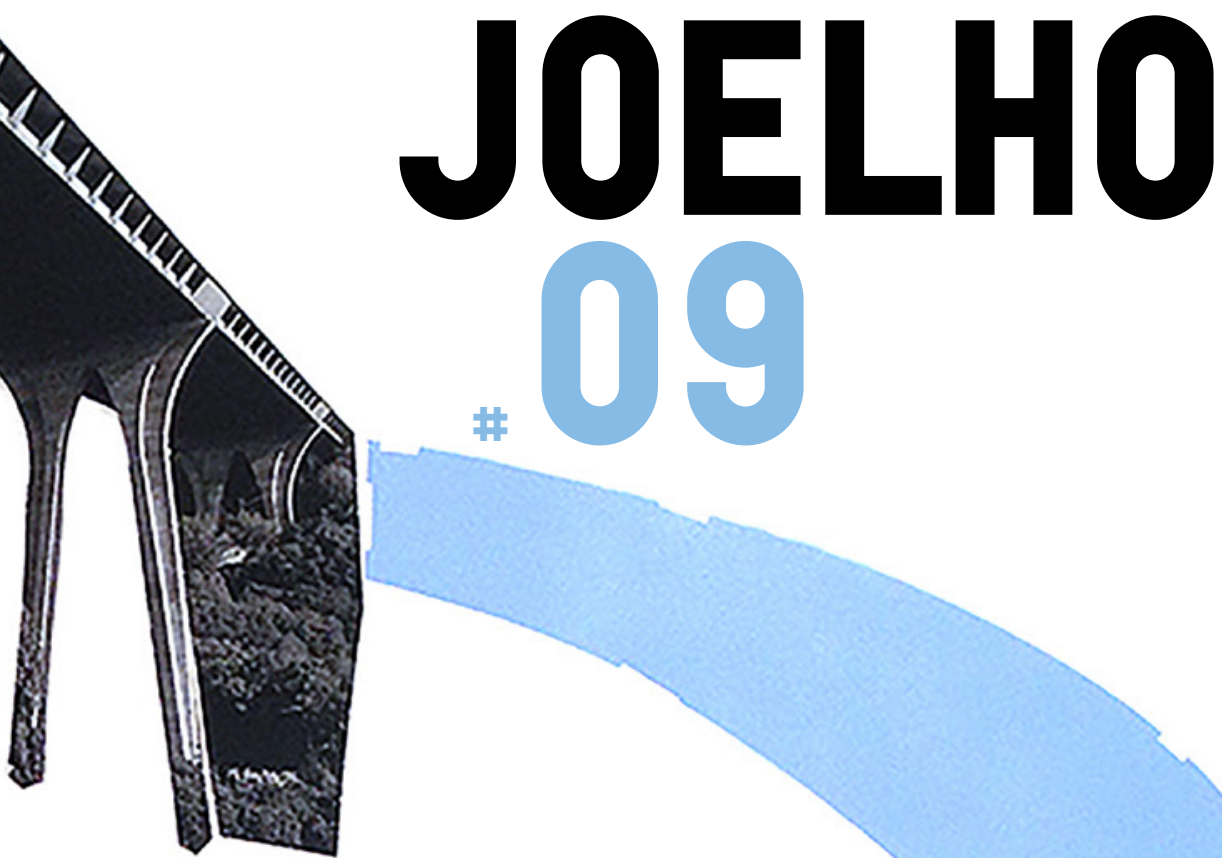

\section{REUSE OF MODERNIST BUILDINGS: PEDAGOGY AND PROFESSION}

Guest Editors:

Michel Melenhorst

Paulo Providência

Gonçalo Canto Moniz

ZUS: Elma van Boxel

and Kristian Koreman

Atelier do Corvo

Tilemachos Andrianopoulos

Albena Yaneva

Carlos Fortuna

Christian Gänshirt

Dieter Leyssen

Carolina Coelho

Anna Giovannelli

António Carvalho

Marta Peixoto

Els De Vos

and Eva Storgaard

Exhibition

$2^{\text {nd }}$ RMB Workshop, Coimbra

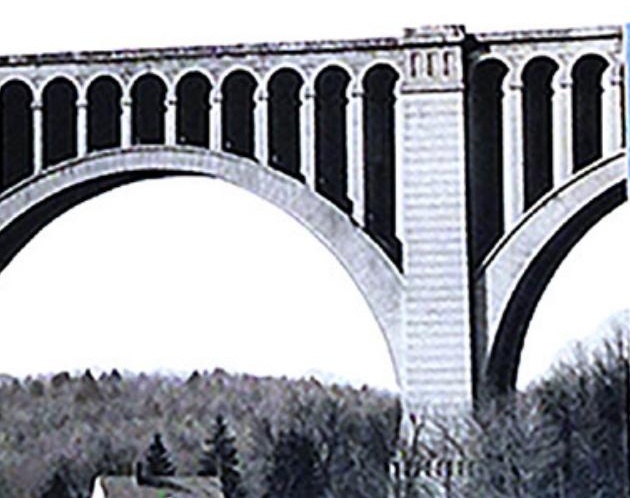


'T'hree times Modern: three projects, three diffrerent spheres, and scales; three diffrerent stories
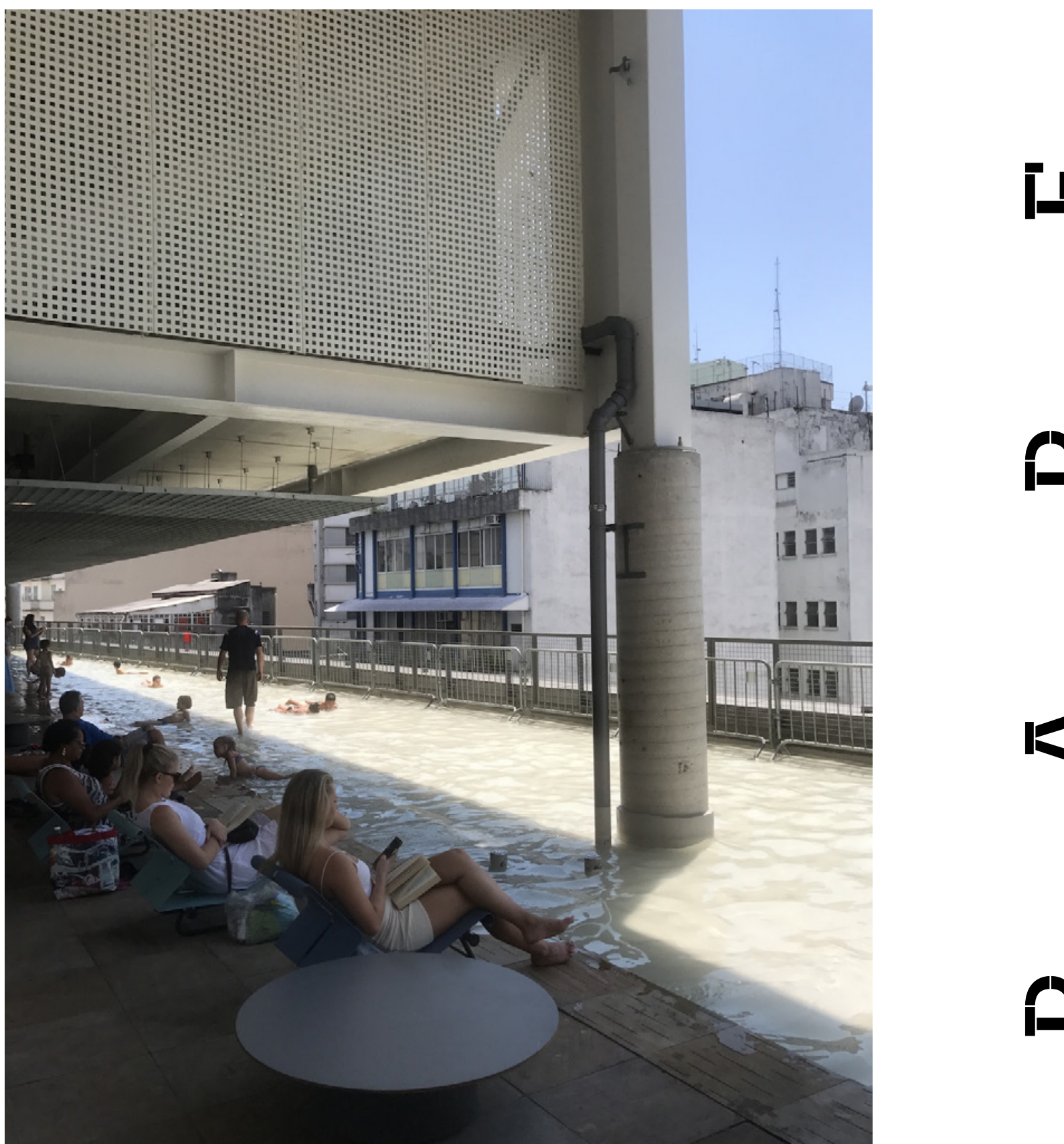
This article intends, through the observation of three different projects of Brazilian architecture, to embrace broad and essential issues such as modern heritage and the reuse of modern buildings. The case studies are Casa de Vidro (Lina Bo Bardi, 1950-51), Prudência apartment (Andrade Morettin, 2001-O2), and SESC 24 de Maio (Paulo Mendes da Rocha, 2000-17). An extraordinary modern house in its different phases, a recent renovation of an apartment from the 1950s, and the transformation of a commercial building that used to host a famous department store in the 1970s into a cultural and leisure center, all in São Paulo, Brazil. The text is about these projects, buildings and their interiors, the transformations they have gone through - or not - along with their natural aging process, and the actions that the specialized organs and the society have taken - or not - concerning these modifications. They were chosen more for their discrepancies than for their similarities, in order to create a broad representative picture of how modern heritage is treated in Brazil.

This observation does not reach definitive conclusions but allows to raise some critical issues for debate, such as the differences in the preservation and renovation of interiors and buildings, public or private, small or big ones, and the challenges to protect something alive and changeable like buildings and their interiors. Also, the difficulty of understanding interiors as an active part of the heritage to be preserved, as an integral part of the architectural design, and differences between maintenance and renovation design practices.

\section{First case: Casa de Vidro}

Casa de Vidro stands on slender pilotis, on a very steep slope, almost devoid of vegetation at the time of its conclusion. The place is Morumbi, then a new neighborhood, designed in 1948, in the southwest of the city center, resulting from the allotment of small farms, inspired by garden cities. The lots were very generous, and soon many of the wealthy families of São Paulo settled in the winding streets of the region.

The house is composed of a large suspended volume, letting the natural site practically intact. It is a rectangle composed of two parts nearly the same size: the social area, that is a spacious glassed-in room, and the private wing, consisting of two tracks of rooms separated by a courtyard. The access is from below, where an open and very light metal stairway leads to the first floor, where the house itself is.

The social area, where three of its four façades are made of glass, is the glass case itself, organized into four spaces, which are a library, a living room, a fireplace, and a dining area. The roof is a concrete slab divided into two plans slightly inclined, like a gable roof, and the glass façade is free from the pilotis, which are further inside the house perimeter. The framed windowpanes reach from the floor to the ceiling and slide like doors, yet there is not a balustrade.

When it was built, the house designed by Lina Bo Bardi for her and her husband, the Marchand Pietro Maria Bardi, revealed an eclectic
Frontispiece (Fig. 9) The water mirror on the eleventh floor. Photo taken by the author, 2017. 
Fig. 1 Casa de Vidro from the outside at the time of its conclusion. Photo was taken by Francisco Albuquerque. Retrieved in the book Modern Architecture in Brazil, written by Henrique Mindlin.

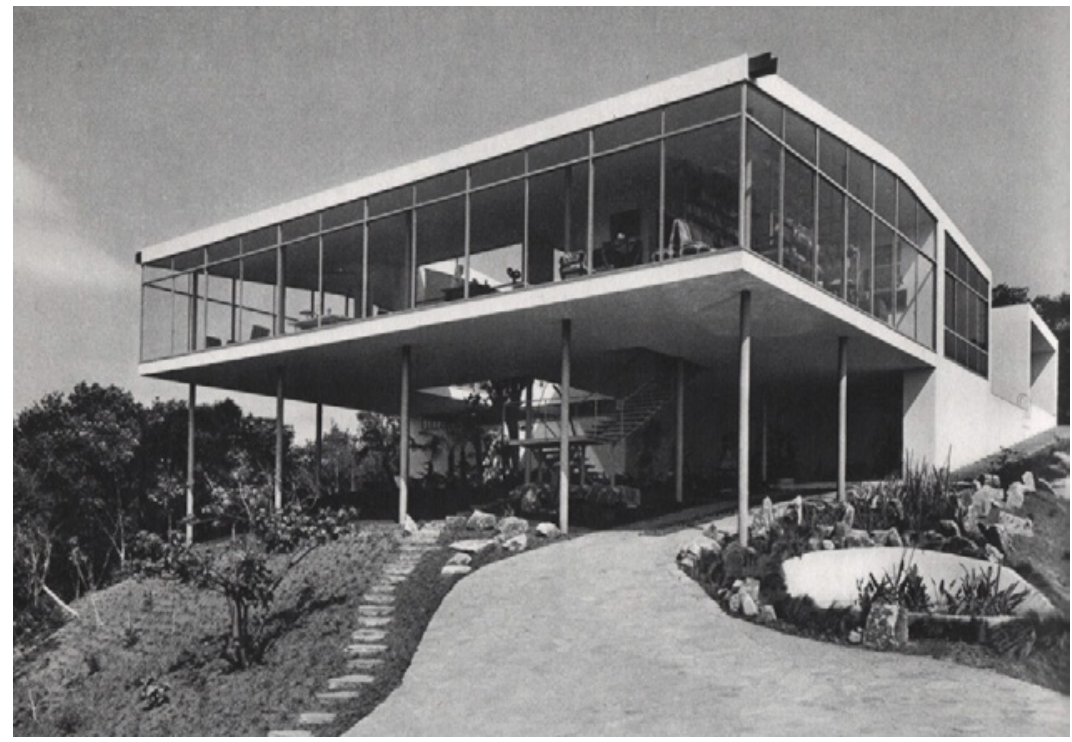

sensibility, combining contemporary furniture with valuable antiques inside the glass box. It displayed a stripped-down, balanced and restrained interior, even if somewhat diverse. The ambiance was naked, with a low density of objects and furnishing.

Over time, a gradual process of accumulation led to another arrangement in the social areas - the transparent box indeed. The images showing the collection of furniture and objects without concern for the formation of specific sets, placed on floral rugs arranged without much relation to the general layout, is from the 1990 s when the house was 40 years old. Then the Baroque statues and the original Renaissance Cassoni began to live side by side with everyday crafts, colonial artifacts, Art Nouveau vases, contemporary design furniture, ordinary furniture, and even some knick-knackery.

The casing was the same, although a little worn, but the internal settings changed a lot - this transformation is remarkable in the social sector of the house, even because the bedrooms area hardly appear in the published images and the services remain almost unchanged. There was a density of objects and furniture which was impressive, especially when compared to the original version. House and architect aged, and as a result, we had two different versions of the same house. There was a change in the original interior of Casa de Vidro; considering Architecture as a total design, even if made by the author, the project changed as a whole.

In 1990, forty years after the house opening, the couple founded an institution based there - Instituto Lina Bo e P.M. Bardi - to spread the knowledge of Brazilian art and culture internationally. Lina Bo Bardi died in 1992, and her widower donated Casa de Vidro to that institution in 1995. Although listed (in 1987 and 1991, by the state and the city, respectively) much of its content was taken by his descendants after 
Pietro Maria's death, in 1999. Although protected as a national heritage in 2009 , the house that is now the headquarters of the Instituto Lina Bo e P.M. Bardi is, in fact, the third version of Casa de Vidro, very different from the two previous ones. The building remains the same, but it is no longer a house and the museum in which it has turned into exhibits other things than its original content.

In 2016, Casa de Vidro received financial assistance from the Getty Foundation through "Keep it Modern," an international grant initiative which aims to support the preservation of modern architectural heritage. The money has been used to carry out management and preventive maintenance plan to avoid emergency interventions and constant repairs. The primary focus is the reinforced concrete structure. The interior does not even come into question.

By the end of June 2018, there was an exhibition called "The house as a home," which tried to reproduce the routine of the couple inside their home. Then, the interior of the house is now a memory, and no longer a reality. In Lina Bo Bardi's conception, Casa de Vidro - and architecture, in general - was a whole thing: the building and its interior. What is done here today is the preservation of the building itself, which means the conservation and maintenance of the box that housed Casa de Vidro in the past. This action is not the same thing as preserving the house designed - and lived - by Lina Bo Bardi.

\section{The second case: Prudência apartment}

Prudência building is a project by the architects Rino Levi and Roberto Cerqueira Cezar (1944-1948). It is on Higienópolis Avenue, in the neighborhood of the same name. The lot is in the middle of the block, and the building is a unique and loose volume in the shape of a "U," creating a patio oriented towards the courtyard. In the strip between the path and the hall, there is a garden designed by Burle Marx, with a couple of winding ramps that lead to the entrance, half a floor above street level. One at each end of the side parallel to the street, the ramps lead to two independent entrance halls, where Burle Marx also designed the facing tiles. Two other central slopes lead to the semi-buried garage. These spaces are the only closed volumes on the ground floor, marked by the fluidity of the pilotis. Above it, there are nine floors with four apartments each, and one more floor with two attics. The size of the apartments is very generous, between 315 and $360 \mathrm{~m} 2$, and each axis of vertical circulation serves two flats on each floor. The social and private areas turn to the street or the sides of the lot, whereas the service areas open to the courtyard.

The original project consisted of a free floor, where the owner would receive an apartment without internal divisions, but the idea was not well accepted, and only one resident agreed with the proposal. Then, almost all the flats were the same, with four principal bedrooms, a dining room, and a living room. There were two entrances, one social and one service. The social door led to a hall, followed by a passage that
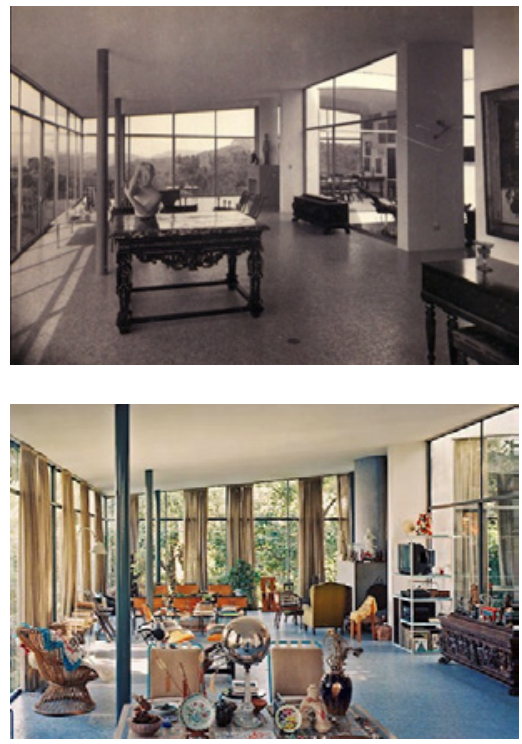

Fig. 2 Casa de Vidro from the outside at the time of its conclusion. Photo was taken by Francisco Albuquerque. Retrieved in the book Modern Architecture in Brazil, written by Henrique Mindlin.

Fig. 3 Casa de Vidro interiors in the1980s. Photo was taken by Nelson Kon. Retrieved in the book Lina Bo Bardi. Obra construída. Built work, written by Olívia de Oliveira. 


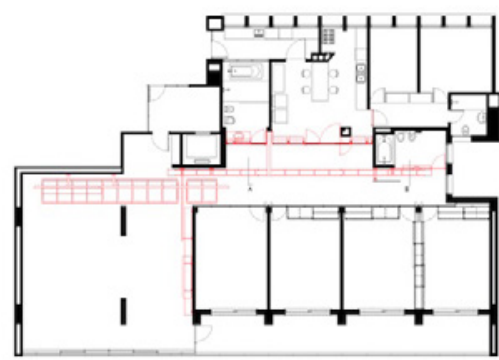

Fig. 4 The renovation plan. Source: retrieved July 08, 2018, from http://andrademorettin.com. br/projetos/reforma-prudencia/ divided two distinct parts: the social and private areas, and the service area. Instead of walls, the space of the corridor was composed of carpentry and already appeared in the original project. Likewise, on the internal façade that separated the rooms from the balcony, the furniture made the role of a balustrade, and above it was the glass window.

The solution of the structural system allowed flexibility in the use of all the spaces, but this capability was availed only in the social and private areas. In the area occupied by the services and oriented towards the inner part of the "U," there were a series of small rooms, such as bathrooms, servants and storage rooms, in an intricate setting.

Prudência was listed in 1994, but only its external envelope, as in most cases in Brazil - the building is considered worthy of protection, while the interior is not. Thus, the internal modifications do not require any control beyond the regular ones, applied to any ordinary renovation. In this context, in 2001, the office Andrade Morettin, from São Paulo, was hired to renovate one of these apartments of Prudência. The clients were a couple with only one daughter, and changes were made to adapt it to the family lifestyle. In addition to the central family nucleus, a nephew was going to live with them for a period. The requested program was a suite for the couple, three bedrooms (one for the daughter, one for the nephew and another one for guests), integrated living and dining rooms, a kitchen, a small office, and services connected to the social space, in addition to the modernization of the installations.

The synthesis of the architect's proposal is the insertion of one large equipment in the corridor, to completely transform the relationship among the internal spaces, mainly between the services and the main areas. This relationship, previously rigid and insufficient, became fluid and changing. This element is composed of panels that move and allow the integration of all spaces. Also, it assumes different roles as infrastructure (support for technical installations such as electricity and plumbing), shelves, storage, and display of art and objects.

This large piece of furniture is made of bent and pre-painted steel sheets and tempered glass sheets. The idea is that it does not touch the original apartment. More than a layout solution, this piece identifies and makes clear what is designed by them and what is from the 1940s. The white floor in this area helps to mark the renovation work.

Prudência is an example of a much broader phenomenon that happens in many Brazilian cities, which is the renovation of apartments in Mid-twentieth century buildings. Regarding the internal space, these renovations convert the old apartments into even more modern ambiances than they were at the time of their construction. The integrated layouts and fluid spaces, visually connected to the outside that was idealized by Modern Architecture, appear in the works of the 2000s, and not in the original occupations. In the 1950s the box was much more "modern" than its content. 

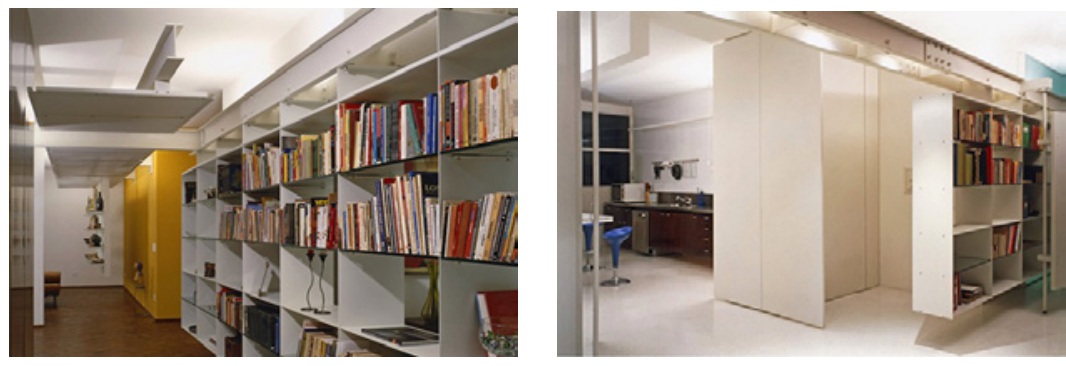

Fig. 5 The large equipment in the corridor. Source: retrieved July 08, 2018, from http:// andrademorettin.com.br/projetos/reformaprudencia/

In addition to the physical and structural transformations, the renewed apartments are characterized by producing modern internal environments, more homogeneous and stripped, with little density of objects and furniture, which are close to emblematic proposals such as those that emerged in Europe in the 1920s and 1930s. In these contemporary interventions, frequently the materials of the walls and the structure are left raw and insight; the curtains and much of the fabrics disappear, and most of the few loose pieces of furniture arranged internally are from the 1950 - the same age as the building.

It seems that these apartments were only completed in one unit in the years 2000s, when the interior tunes to the "envelope," and together they become a harmonious whole. Finally, they manage to be entirely modern. The irony is that the building itself is fifty years old.

\section{The third case: SESC 24 de Maio}

SESC (Serviço Social do Comércio) is a non-profit private Institution that has operated in Brazil since 1946, supported by mandatory contributions, made by commerce businessmen and focused primarily on the social well-being of its employees and family members. First (1976-86), Lina Bo Bardi recycled a red-brick building that had housed a drum factory in the Pompéia neighborhood, in the same city of São Paulo, that became the Centro de Lazer Fábrica da Pompéia (Pompéia Factory Leisure Centre), known just as SESC Pompéia, an architectural landmark. The complex became an undeniable success.

This one enterprise, SESC 24 de Maio, was inaugurated last year, in the heart of São Paulo downtown. Abandoned by the upper classes since the 1970s, the city center remains a highly vital and accessible area, punctuated by remarkable structures and significant cultural institutions.

The corner lot is about 40 meters along the pedestrian street D. José de Barros, and about 60 meters along 24 de Maio st., one block away from Praça da República and from Municipal Theater. Paulo Mendes da Rocha led the process of 17 years of design and construction (2000-17) assisted by MMBB Arquitetura e Urbanismo principals, Marta Moreira, and Milton Braga. They did not put down the 12-story building that occupied the lot, formerly a well-known - and already bankrupt - department store called Mesbla, but recycled it selectively, 
Fig. 6 The open swimming pool at the terrace. Photo taken by the author, 2017.

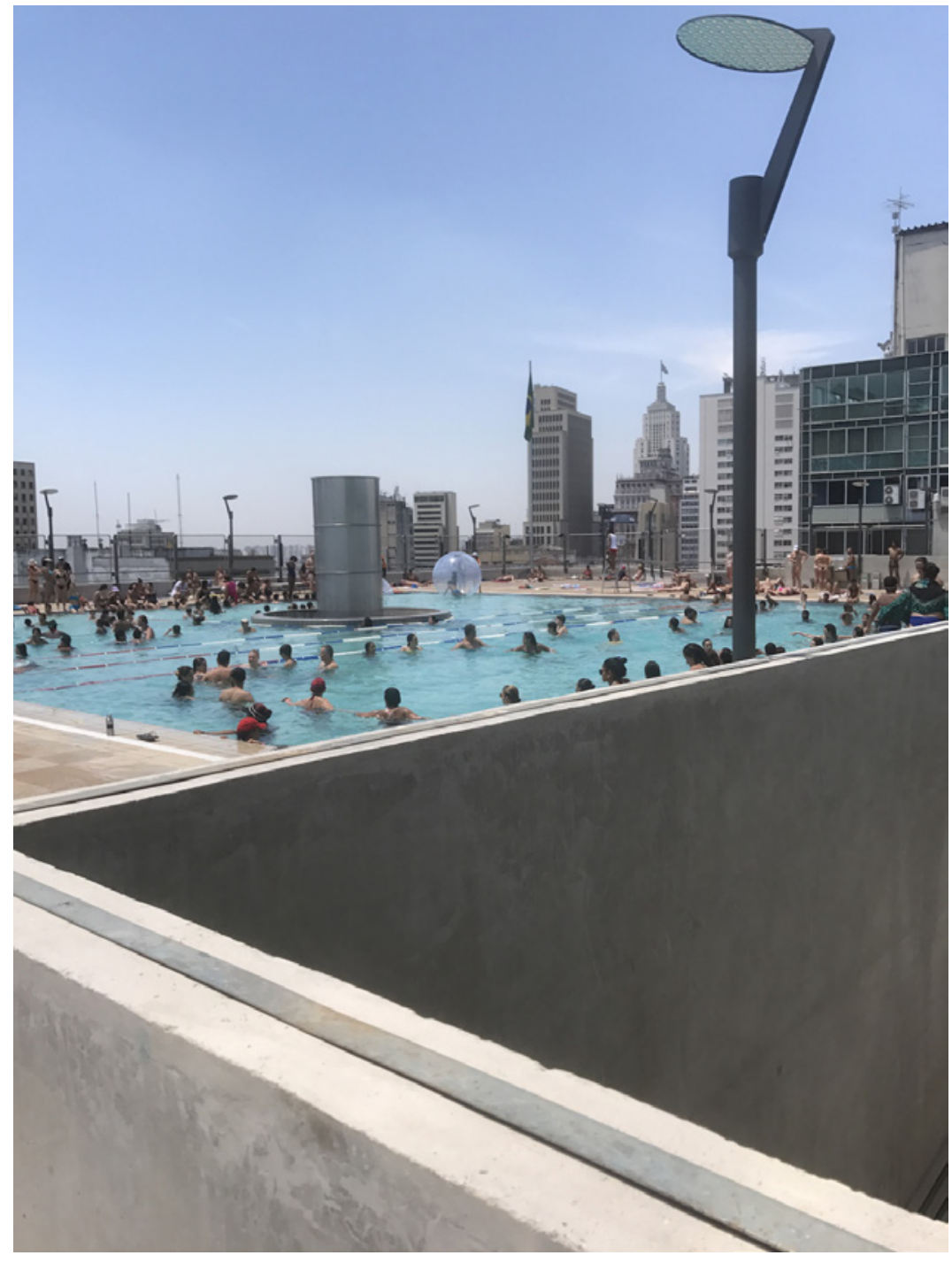

emptied it to the bones and demolished lumps to create a U-shaped volume. In its center, he inserted four pillars that support a new terrace with a swimming pool, the capital gesture of the project.

The lateral clearance along the border of 24 de Maio street housed elevators, stairs, balconies, and lighting wells. The lateral clearance along the border of $\mathrm{D}$. José de Barros street housed ramps that propose a vertical architectural walk, articulated with the circular route on the various pavements. On the other hand, the 8-story commercial building in the narrow adjacent lot was the Fasano Vertical Restaurant (1964), by Telesforo Cristofani (1929-2002), a fellow student of Mendes da Rocha; SESC bought it - a suggestion of the architects - and they replaced it by a service tower.

There is a theater in the underground, and just above it, on the street level, is the large access plaza designed as an urban lounge, a 

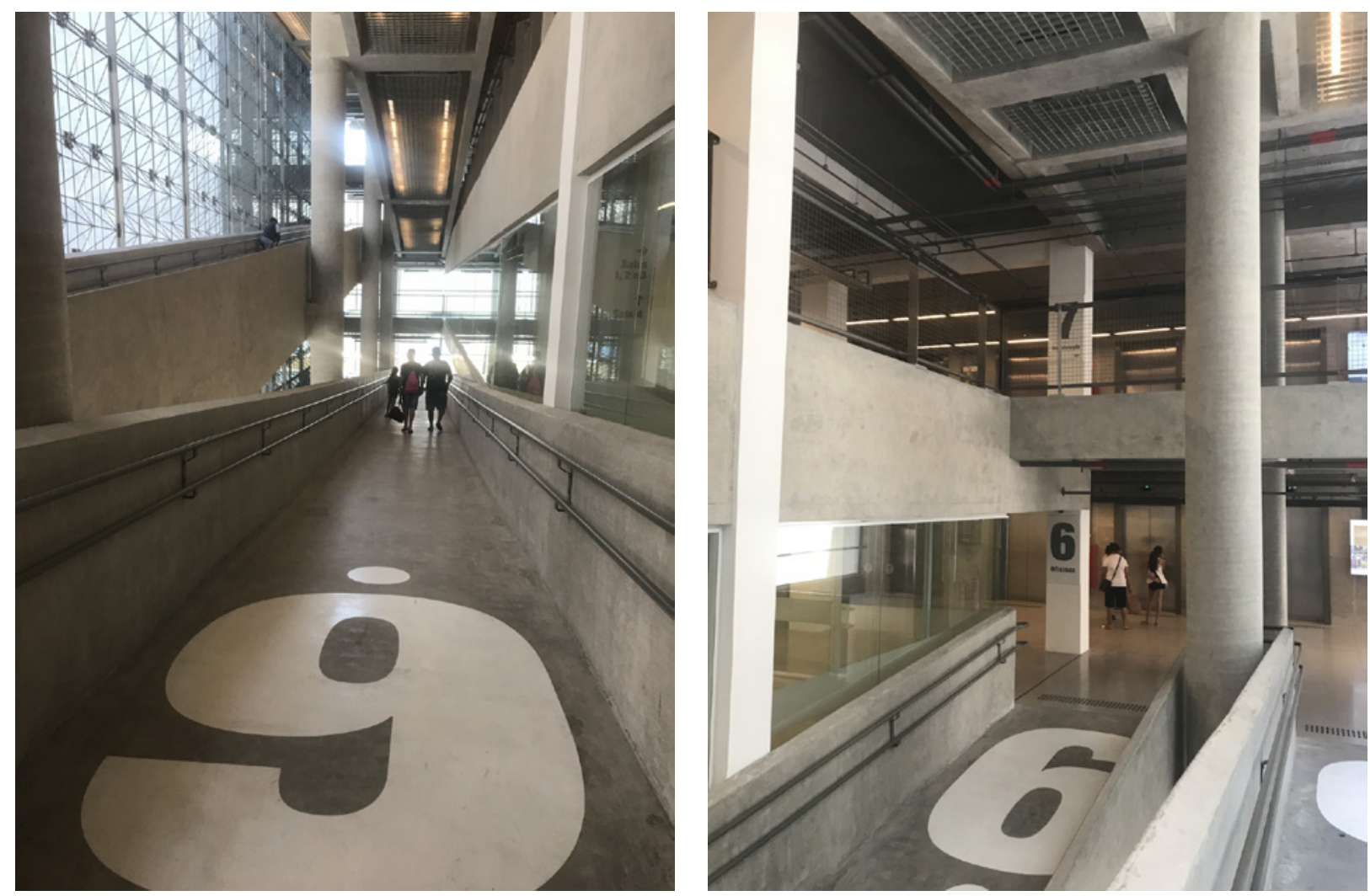

welcoming space. The pallets created for this area respond well to its dimensions; like couches, they suggest reclining or lying positions. The perimeter of the building is permeable on this floor, ensuring the free transit of pedestrians. The reception is located in a chamfered triangular volume, painted in pink, that lead the public into the building interior. Above it is the administration.

Then, from there to the top, a rational zoning organizes the different sectors on the other twelve pavements. First is the restaurant, which is for public use. Then living spaces, culture (a library, exhibition room, and workshops), dental offices and sports (courts, exercise areas, and the pool). Some of these floors - like the exhibition room, and the workshops - are associated two by two to mark essential spaces with double height and avoid the monotony of simple overlapping type floors. However, the last two are the top ones. On the eleventh floor (christened the pool garden), conceived as a covered square or a hanging garden, without side closure, there is a reflecting water mirror which extends along the two façades and works like a vast cooling basin. At last, there is the swimming pool, open to the sky, crowded for most of the year.

The old reinforced concrete was scraped. The new concrete was poured into cardboard and plywood plates molds, ensuring a soft texture. The resulting set is a hybrid structure, partly original and partly
Fig. 7 The ramps that propose a vertical promenade. Photo taken by the author, 2017. 
Fig. 8 The pallets lounge. Photo taken by the author, 2017.

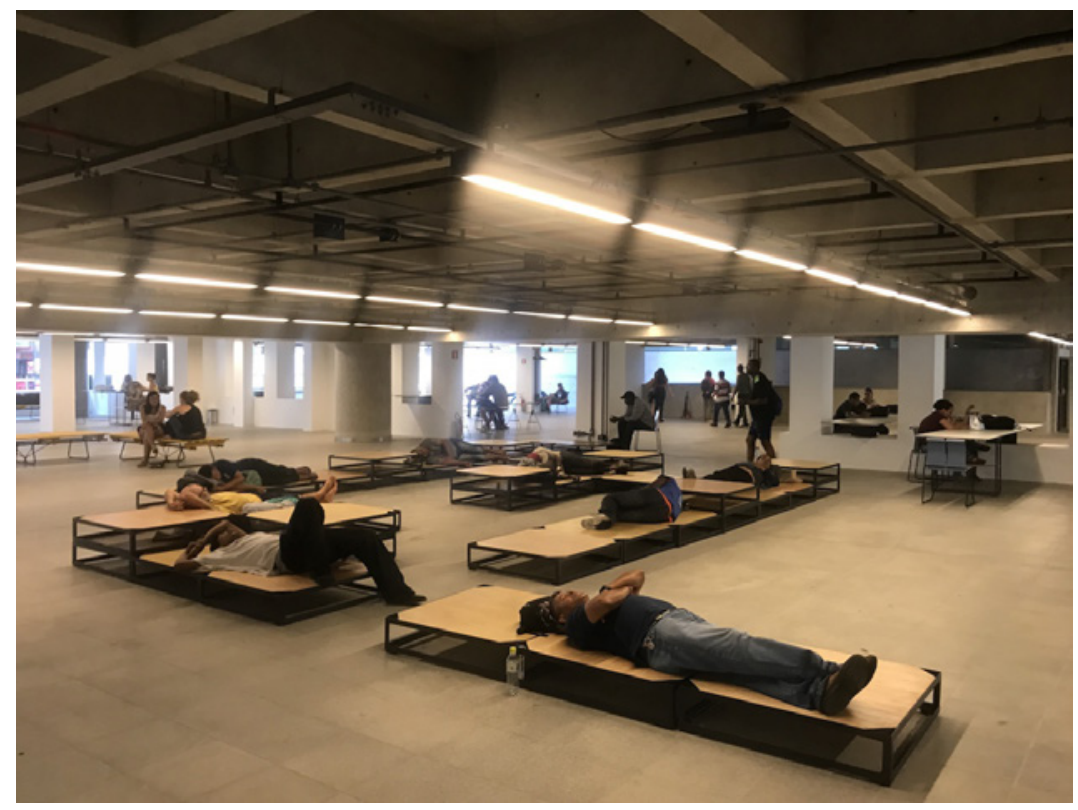

added. The façade was shrouded by a curtain wall that reflects, in a distorted way, the nearby commercial galleries. Inside, everything is transparency, in the best modern tradition of the free plan and façade. Besides, there is the free sheet metal and tubular steel furniture, one of the highlights of the project.

Much more than the renovation of an ordinary modern building, SESC 24 de Maio recovers a memorable place of the city and promotes a renewal of a portion of São Paulo's downtown. Its predecessor, SESC Pompeia (listed as heritage in 2009) continues as a very successful enterprise since its opening and remains almost the same after thirty years. The same trajectory seems to be the destination of this new point.

\section{Starting to finish}

The first example, Casa de Vidro, was born modern, almost like a manifesto, with its stripped, rarefied and practically homogeneous internal ambiance. Over time, it was somehow "demodernized" by the own hands of Lina Bo Bardi, accumulating various objects, densifying its interior and continuously being updated by its inhabitant author. Moreover, the external environment has also changed considerably, with the increase of the built density and growth of vegetation, as well as the much wear of the building, which suffered from the natural action of time.

After the death of the Bardi couple, however, Casa de Vidro changed its use, in addition to changing owners. Today, it is disfigured internally, although transformed into heritage. Its content has been significantly altered, and the house is no longer a house, unlike other works that have become museums of themselves, like Case Study 


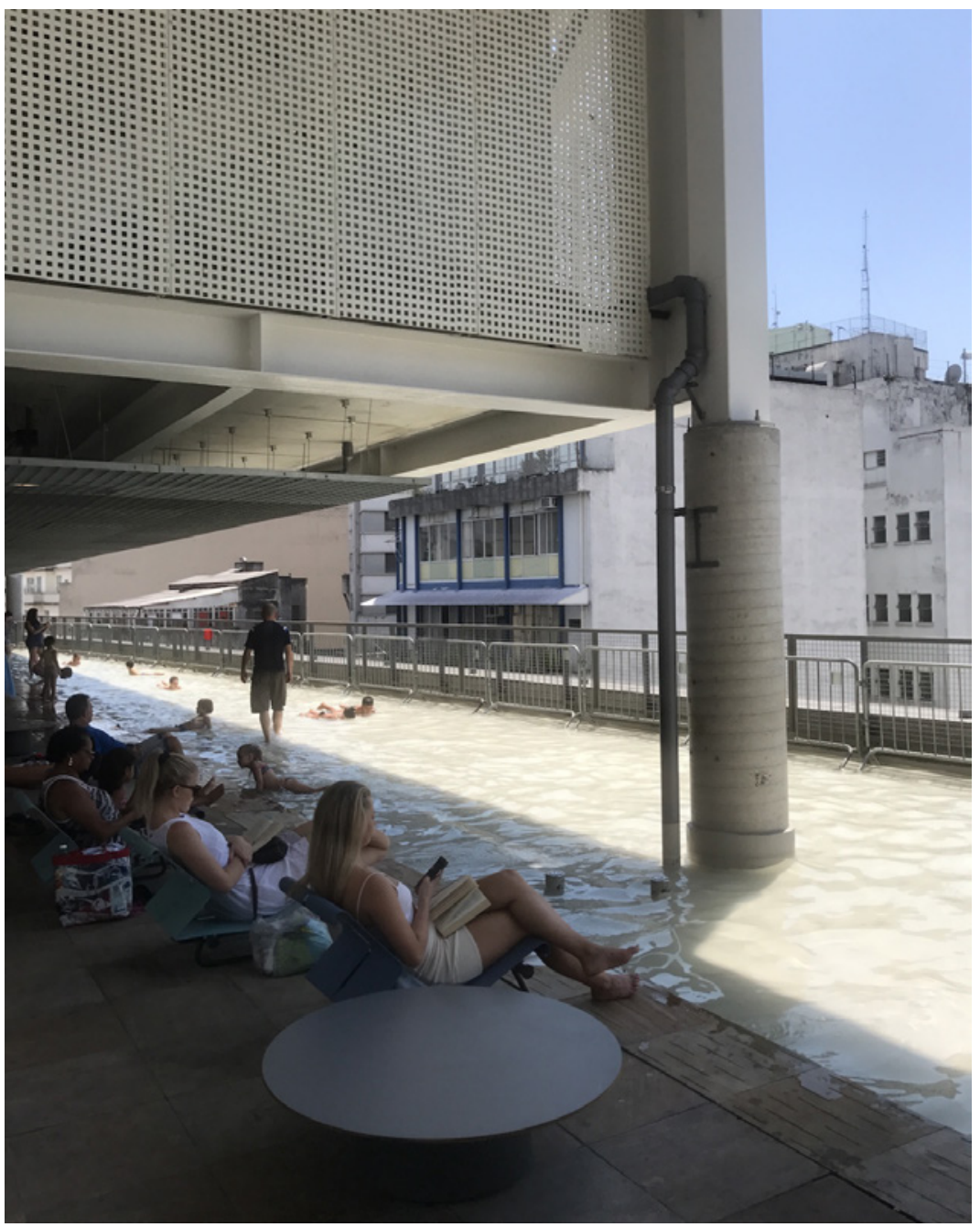

Fig. 9 The water mirror on the eleventh floor. Photo taken by the author, 2017.

Fig. 10 Sheet metal furniture in SESC 24 de Maio. Photo taken by the author, 2017.
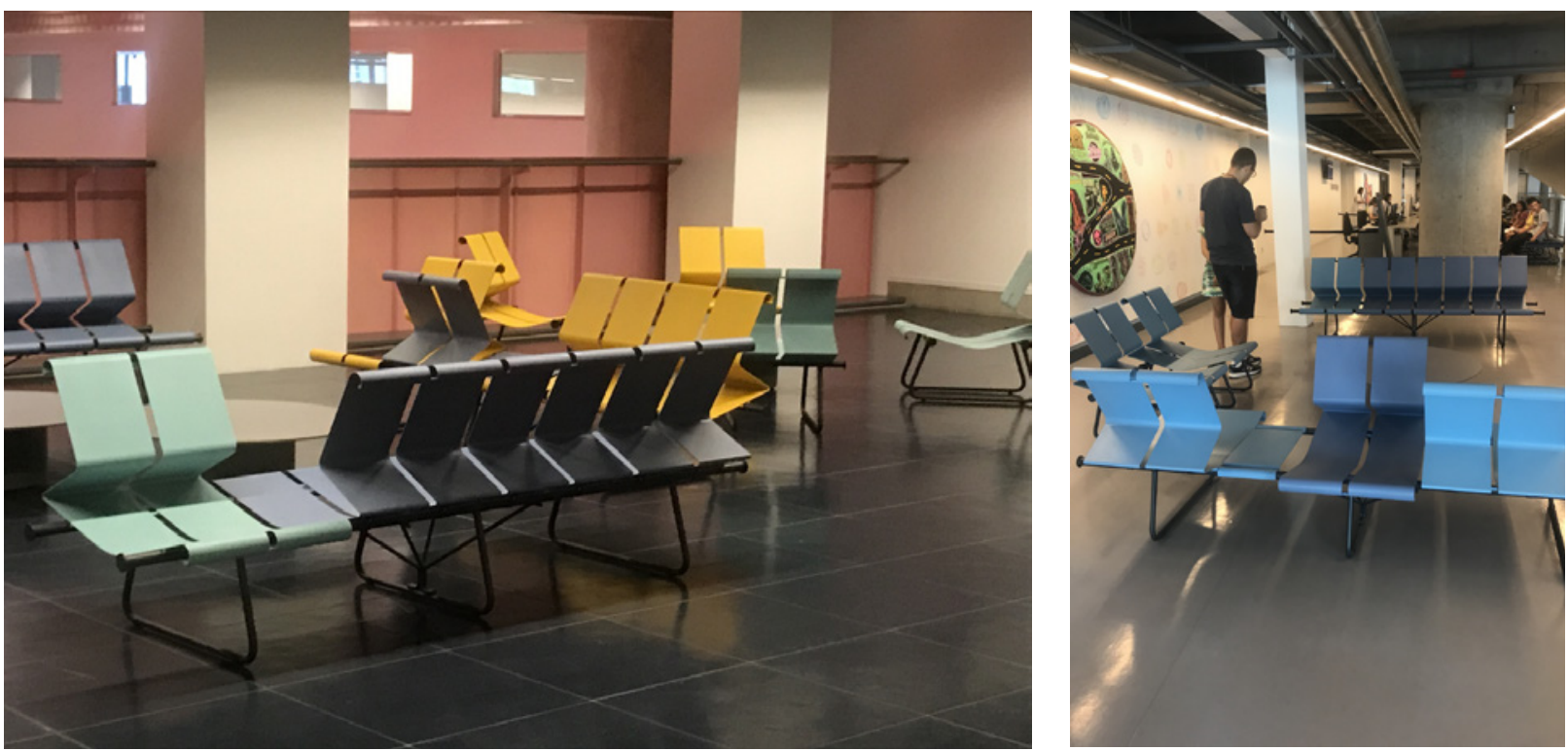
House \# 8, the Eames house, in the United States, which remains intact, as if in use. In the same way as Lina's house, the Eames house was made and inhabited by the author architect (in both cases with the vital participation of the partners, Ray Eames and Pietro Maria Bardi) and both couples tended to accumulate objects around the house. However, Case Study House is intact and shows precisely how its famous residents experienced it. The Eames House, as well as Casa de Vidro, also received support from the Getty Center; in fact, the action implemented in the house was the first of its kind developed by the Getty Conserving Initiative - GCI. The project addressed some interrelated conservation issues that focused on the building envelope and the development of an appropriate environment for the inner fabric of the house, which included its contents and collection, all part of the design legacy of Charles and Ray Eames.

In the North American case, from the beginning, the conception was to protect both: the shell, and everything from the inside. Unfortunately, this process was different in Casa de Vidro, since its internal ambiance has changed a lot as a result of losing much of its content. After all, one misses the dimension of the whole, building and its interiors, which was the author's conception. This is a loss. On the other hand, one has to ask about the real meaning of the maintenance of a frozen house, just as it was when built, restricted in its use for other purposes (perhaps more appropriate to the contemporary situation). After all, it was the wish of the owners, the Bardi couple, that the institute based in the house was a place of propagation of Brazilian culture. In this sense, the house as a cultural center is, undoubtedly, more flexible, and lends itself better to this purpose than if it were set as a home. Besides, 1990s version of the house was also no longer the same as the 1950s since its interiors have changed considerably, even though it was the author who produced the change. This behavior may reveal, somehow, how Lina felt about changes.

The academic criticism accepted the modifications made by her. Besides, the second version is even more Casa de Vidro than the first one. Finally, the version that survived the death of the owners is different from the two previous ones, reduced to little more than the building, even after the house was declared heritage.

One way or another, as a cultural building it suffers from the same lack of money sustained by most cultural institutions in Brazil. If on the one hand, it is interesting that the house is not treated as a private building - which prevents it from falling into the hands of anybody - on the other hand, it has severe conservation and maintenance problems. Fortunately, the Getty Center project provided essential help.

The apartments are a different case, as much as in scale, importance, and history. The buildings where such contemporary renovations take place are often exemplary, worthy of protection - in fact, many of them are listed by heritage, as Prudência. The upgrades currently carried out keep the same program, even if changed due 
to the new demands. These are smaller-scale actions, private and restricted to the interior of the apartments. Although more ordinary and not necessarily as good as the original projects, they ensure the preservation and enhancement of the existing buildings through a small-scale action which has gained importance and attention because of the frequency in which it is made today.

As they happen in a private interior, there is no greater involvement of protective organs, and the original apartments can change deeply - the Andrade Morretin renovation, for example, happened after Prudência was listed. This proceeding is partly due to a general understanding of protection restricted to the building, as in the case of Casa de Vidro. On the other hand, it is clear that the preservation of a complete set of apartments, even in an extraordinary building, would not make sense.

Without changing the original program, these renovations are examples of good private practice, carried out with private resources, which value modern heritage and create contemporary products, instead of untouchable historical artifacts. They are daily works, even if existing in exceptional buildings. Buildings that were good in 1950, and maybe now, seventy years after their construction, they are even better because, finally, they are complete: the interior and exterior are in tune.

The result of this phenomenon - the renovation of a large number of apartments from the 1950s in the neighborhood of Higienópolis - is the appreciation of the region itself, as well as an update of residents and greater preservation of the buildings without the need for public money. However, there are already discussions about the possibility of controlling these renovation projects by specialized heritage organs. There are those who believe that it is forbidden to change the original plans, and materials or add new installations. Even if based on good intentions, this limitation can be quite dangerous. After all, disregarding the contemporary need for up-to-date facilities may make it unfeasible to use these buildings. Without altering the domestic use, there are considerable changes in these renovations. In return, the building is preserved.

Finally, there is the example of SESC 24 de Maio, evidently of another scale, involving other factors. From the starting point this is a different situation since in the example of SESC the original building is not the highest value work, but the renovation executed on it, and the urban appreciation. Actually, one of the existing modern buildings was destroyed, and the other one was quite transformed.

Besides, there is a powerful organization behind the action. Moreover, this entity often invests in Architecture as a distinction of its projects. SESC ventures, furthermore reaching countless associates, are maintained by excellent management, which conserves and directs their undertakings in a way that is always successful. This success ensures maintenance. 
The institution SESC invests in architecture as a mark of its enterprises, no doubt. Moreover, many of these are carried out in lesserknown buildings - or that have value only to a small community - in less-valued land areas, not only in the recovery of built-up heritage and forgotten areas but also as an intelligent strategy, in the sense of financial assets. As a consequence, in addition to the facility itself, there is a return for the city, recovering the vitality of some of its spaces, and approaching ordinary citizens, which is the lower-middle class public, the typical member of SESC, to good architecture - something unfortunately uncommon in Brazil. It is a broad-spectrum gain, with no - or little - public money.

These are three very different cases, no doubt. However, despite their differences - or even because of them - they can draw an illustrative picture of how modern interiors, modern heritage, modern heritage maintenance, and modern heritage renovation are being carried out in Brazil. Also, point out some of the discussions and reflections that we have to take forward, such as the role and performance of heritage organs, private agents and architects in the process of reuse modern buildings. As in designing or creating new buildings, this is a scope where it is possible to observe some consensus guidelines, but no rigid pre-established rules or general strategies.

References

Bo Bardi, L. (1953). Residência no Morumbí. Revista Habitat, 10, 31-39.

-

Comas, C.E. (1997). Lina Bo Bardi. Revista de cultura brasileña, 2, 100-121.

Ferraz, M. (Org.). (1994). Casa de Vidro. Glass House. Editorial Blau e Instituto Lina Bo e P.M. Bardi: Lisboa e São Paulo.

-

Lima, Z (2013). Lina Bo Bardi. New Haven and London: Yale University Press.
Mindlin, H. (1956). Modern Architecture in Brazil. New York: Reinhold.

Oliveira, O. (2014). Lina Bo Bardi. Obra construida. Built work. Barcelona: Editorial Gustavo Gili.

-

Solà-Morales, I. (1982). Teorias de la intervención arquitectonica. Quaderns, 155, 30-37.

Serapião, F. (2014). Moderno nas Alturas. Monolito, 19, 14-26.
Zein, R.V. (2000). Arquitetura brasileira, Escola Paulista e as casas de Paulo Mendes da Rocha. Masters dissertation, Universidade Federal do Rio Grande do Sul - Programa de pós-graduação em Arquitetura, Porto Alegre, Brasil.

-

Zein, R.V. (2005). Arquitetura da Escola Paulista Brutalista, 1953-1973. Doctoral thesis, Universidade Federal do Rio Grande do Sul Programa de pós-graduação em Arquitetura, Porto Alegre, Brasil. 